\title{
Awareness and Knowledge of the Sustainable Development Goals in a University Community in Southwestern Nigeria
}

\author{
Omisore Akinlolu $\mathrm{G}^{1}$, Babarinde Grace $\mathrm{M}^{\mathbf{1}}$, Bakare Damilola $\mathrm{P}^{\mathbf{1}}$, Asekun- \\ Olarinmoye Esther O.
}

\author{
OPEN ACCESS \\ Citation: Omisore Akinlolu $\mathrm{G}^{1}$ \\ Babarinde Grace $\mathrm{M}^{1 *}$, Bakare Damilola \\ $\mathrm{P}^{1 *}$, Asekun-Olarinmoye Esther O. ${ }^{1}$ \\ Awareness and Knowledge of the \\ Sustainable Development Goals in a \\ University Community in Southwestern \\ Nigeria. Ethiop J Health \\ Sci.2017;27(6):669. \\ doi:http://dx.doi.org/10.4314/ejhs.v27i6.1 \\ 2 \\ Received: June 3, 2017 \\ Accepted: June 19, 2017 \\ Published: November 1, 2017 \\ Copyright: (c) 2017 Omisare G., et al. \\ This is an open access article distributed \\ under the terms of the Creative Commons \\ Attribution License, which permits \\ unrestricted use, distribution, and \\ reproduction in any medium, provided the \\ original author and source are credited. \\ Funding: Nil. \\ Competing Interests: The authors \\ declare that this manuscript was approved \\ by all authors in its form and that no \\ competing interest exists. \\ Affiliation and Correspondence: \\ ${ }^{1}$ Department of Community Medicine, \\ Osun State University Osogbo. \\ Student, BSc. in Public Health. \\ Email:akinlolu.omisore@uniosun.edu. \\ ng, akinloluwaomisore@gmail.com
}

\section{ABSTRACT}

BACKGROUND: The Sustainable Development Goals (SDGs) is a globally accepted developmental agenda, and it is expected that everyone everywhere in the world would be aware, knowledgeable and be willing to contribute to its attainment. This study aims to assess the level of awareness, knowledge of, and attitudes towards the SDGs among members of a university community.

METHODS: A cross-sectional survey was conducted on 450 students and staff of Osun State University, Southwestern Nigeria, selected from three of its six multi-campuses via multistage sampling. Data were collected by means of semi-structured questionnaire. Data were analysed using SPSS version 20.0.

RESULTS: The mean age for the respondents was 26(10.2) years. Only $43 \%$ of the respondents were aware of the SDGs and only $4.2 \%$ had good knowledge of the SDGs. However, 56.3\% had positive attitude towards it. More respondents with good knowledge of the SDGs were either acadenic staff or those have been enlightened via personal study of the SDGs or through other means. Similarly having a positive attitude was associated with being an academic staff/ high level of education as well as belonging to the middle age group. $\quad(p<0.05)$.

CONCLUSION: The awareness of and attitudes towards the SDGs was just fair. However, the level of knowledge was abysmally low, and this has serious negative implications for SDGs attainment. Pertinent individual and population-level methods of enlightening people about the SDGs must be put in place in educational settings; curricular changes are imperative. KEYWORDS: Attitudes, Awareness, Knowledge, MDGs, SDGs, University

\section{INTRODUCTION}

The Sustainable Development Goals (SDGs) is the successor to the Millennium Development Goals (MDGs) and is widely known as Agenda 2030, with reference to the end year by which the SDGs should have been attained globally (1). The MDGs, while it lasted 
was a focal point of the world's developmental agenda and brought about novel and innovative partnerships and considerable development to both developing and developed countries (2). The SDGs represents a more comprehensive agenda than the MDGs with 17 goals, 169 targets and well over 200 indicators (3). The SDGs involves a five "Ps" agenda: people, prosperity, planet, peace and partnership and these five "Ps" are for all countries and peoples of the world $(1,4)$. Global consultations among various bodies/sectors including governments, civil society organizations, the private sector, scientists, academicians and individual citizens were made before the SDGs were put in place. Thus, the educational sector was not left out of its formulation.

The role of education (with SDGs enlightenment as its central focus) is central to achieving the SDGs. just as Health Education is central to Primary Health Care. The United Nations' Educational and Scientific and Cultural Organization (UNESCO) recognizes that education is a major key to sustainable development with its statement "Sustainable development cannot be achieved by technological solutions, political regulation or financial instruments alone. We need to change the way we think and act. This requires quality education and learning for sustainable development at all levels and in all social contexts"(5).

African countries, including Nigeria, were reported to have had a very slow start to the MDGs and this was a major impediment to the achievement of the MDGs (6-8).Perhaps the slow start to the MDGs was probably not unconnected with the low level of awareness and knowledge on the MDGs initially among the populace. It is plausible that if the level of societal awareness is high, various stakeholders from varying sectors can challenge governments to implement global development plans nationally. Universities are higher educational institutions often regarded as the ivory towers of learning, and thus, it is imperative that the level of awareness and knowledge about the SDGs should be explored in a university setting so that possible gaps can be identified and addressed. The university system is made up of lecturers who teach, students who learn and administrative staff standing as an expedient support to both students and staff. Teaching and learning about the SDGs are thus important in the university setting, not only to academic staff and students but also the nonacademic staff since no one is to be left behind when it comes to the SDGs. Thus, this study seeks to assess the perspectives of all members of a university community on the SDGs with a view to appraising the implications not just for the academic community but for all individuals and groups in developing countries where the level of awareness and knowledge on global developmental agendas such as the MDGs or SDGs are usually low.

\section{METHODS}

The study was carried out at Osun State University in Osun State, Southwestern Nigeria. The university is a multi-campus one with six campuses in six major towns in the state with the main campus situated in Osogbo, the state capital. This was a descriptive cross-sectional study. Data for the study were collected in March 2017.

The study population was made up of students and staff (academic and non-academic) of the university, and the sample size was estimated using the Leslie Fischer's formula using 50\% prevalence as no previous study was found, and a sample size of 384 was obtained. This minimum sample size was increased to 500 to allow for possible non-response and also have adequate numbers for cross tabulations. However, eventually, 450 respondents completed questionnaires. A multi-stage sampling technique which considered campuses, colleges within the campuses, faculties/departments within the colleges and administrative units in each college was employed to recruit participants into the study. Three campuses, four colleges, eight faculties, ten departments and six administrative units or directorates were included in the study. The research instruments was a semi-structured self-administered questionnaires specially designed for the study. The questionnaire was 
validated through the expert review of two public health physicians working in development-related fields, and the reliability estimate via Cronbach Alpha was 0.8. Study variables included sociodemographic data, awareness about, knowledge of and attitude towards SDGs. There were twentyfive knowledge questions. Most of the questions focused on the start date and/or period of the duration of the SDGs, the dimensions of the SDGs and the chronology of the SDGs with regard to the MDGs as well as comparison of their contents. Other pertinent questions were asked. . There were five attitude questions as well. Each knowledge or attitude question correctly answered was assigned a score of one while each wrong answer was assigned zero marks. Any respondent who had up to $50 \%$ of the total mark was assigned as having good knowledge or positive attitude, while those who scored less were classified as having poor knowledge or negative attitude. Ethical permission for the study was acquired from the College of Health Sciences Ethical
Review Committee, Osun State University, and informed consent was obtained from the selected respondents. The data were entered and analysed using IBM SPSS statistics software, version 20. Pertinent frequency distribution tables were generated. The Chi-square test was used to demonstrate relationships between categorical variables, and level of statistical significance was set at $\mathrm{P}$-value $\leq 0.05$.

\section{RESULTS}

Most of the respondents were females (56.7\%), students $(66.9 \%)$ and in the age group of $15-24$ years $(68.0 \%)$. In a similar manner, most of the respondents had an educational status of secondary or post-secondary education at the diploma or similar levels $(72.0 \%)$ and were from the Osogbo/main campus of the university $(46.2 \%)$, as shown in Table 1.Out of the 450 respondents, only $192(42.7 \%)$ had ever heard of the SDGs and were the ones whose data were

Table 1: Socio-demographic characteristics of respondents $(n=450)$.

\begin{tabular}{lll}
\hline VARIABLE & Frequency n=450 & Percentage \\
\hline AGE GROUP [Mean age 26 (10.2) years, Minimum= 16, Maximum=64] & \\
15-24 years (Youths) & 306 & 68.0 \\
25-39 years (Young Adults) & 80 & 17.8 \\
40-64 years (Middle- aged) & 64 & 14.2 \\
SEX & & \\
Male & 195 & 43.3 \\
Female & 255 & 56.7 \\
COLLEGES/ CAMPUSES & 208 & \\
CHS*\& CSET†/ Osogbo Main Campus & 118 & 46.2 \\
Management and Social Sciences/ Okuku & 124 & 26.2 \\
Humanities and Culture/ Ikire & & 27.6 \\
HIGHEST LEVEL OF EDUCATION ATTAINED & 324 & 72.0 \\
Secondary/ Postsecondary Education (PSE)- diplomas etc & 84 & 18.7 \\
PSE (First or Masters' Degree) & 42 & 9.3 \\
PhD equivalent or Higher & & \\
RESPONDENTS' STATUS & 301 & 66.9 \\
Students & 71 & 15.8 \\
Academic Staff & 78 & 17.3 \\
Non Academic Staff & & \\
\hline *CHS- College of Health Sciences, $\dagger$ CSET- College of Science, Engineering $\&$ Technology
\end{tabular}

further analysed in this study, with the exception of the data in Table 2 which is on factors associated with awareness on SDGs. The commonest source of information/awareness about the SDGs was radio/TV (39.6\%); followed by

DOI: http://dx.doi.org/10.4314/ejhs.v27i6.12 
internet (36.5\%), lectures/conferences (35.9\%).multiple answers were allowed.

When asked about the first time they heard of the SDGs, 34(17.7\%) of the 192 respondents said they heard of it in or before the year 2012. In the same vein, when asked about the year the SDGs were adopted by the United Nations(UN), 24 respondents $(12.5 \%)$ stated that it was adopted in or before 2014, with only 29(15\%) stating 2015 as the adoption year.

In Table 2, more people in the middle-age group (84.4\%) were aware of the SDGs compared to young adults (58.8\%) and youths (29.7\%). Similarly, more males $(52.3 \%)$ were aware than females $(35.3 \%)$, more academic staff $(87.3 \%)$ were aware than non-academic staff $(61.5 \%)$ and students $(27.2 \%)$. In the same vein, more respondents who had doctorate $(\mathrm{PhD})$ or higher degree $(90.5 \%)$ were aware than those who had first or master's degrees $(70.2 \%)$ and those who had secondary or post-secondary education, not up to the level of a first degree. More respondents in the "pure and applied sciences" from the College of Health Sciences and College of Science, Engineering and Technology located at the main campus in Osogbo (49.5\%) were aware of the SDGs than those in the social sciences $(39.8 \%)$ and those in the "arts" (33.9\%).

With regard to knowledge, only $4.2 \%$ of the respondents had good knowledge of SDGs. However, for attitude, $56.3 \%$ of the respondents showed positive attitude (Figure 1).

Further individual-level analysis of the attitude questions showed that $29.7 \%$ of the 192 respondents claimed to have had a very good grasp of the SDGs, 30(15.6\%) stated that they did not want to know more about the SDGs, and $75(39.1 \%)$ were not ready to invest their time and efforts in learning more about the SDGs.

Table 2: Respondents' awareness on SDGs related with selected socio-demographic and other characteristics $(n=450)$.

\begin{tabular}{|c|c|c|c|c|}
\hline \multirow[t]{2}{*}{ Variable } & \multirow[t]{2}{*}{ Sub-variables } & \multicolumn{3}{|c|}{ Awareness about SDGs $(n=450)$} \\
\hline & & $\begin{array}{l}\text { No/ Not Sure (\%) } \\
n=258\end{array}$ & $\begin{array}{l}\text { Yes }(\%) \\
n=192\end{array}$ & p value \\
\hline \multirow[t]{3}{*}{ Age-group } & Youths & $215(70.3)$ & $91(29.7)$ & $<0.001$ \\
\hline & Young Adults & $33(41.2)$ & $47(58.8)$ & \\
\hline & Middle- aged & $10(15.6)$ & $54(84.4)$ & \\
\hline \multirow[t]{2}{*}{ Sex } & Male & $93(47.7)$ & $102(52.3)$ & $<0.001$ \\
\hline & Female & $165(64.7)$ & $90(35.3)$ & \\
\hline \multirow{3}{*}{$\begin{array}{l}\text { Colleges/ } \\
\text { Campuses }\end{array}$} & CHS \& CSET/ Osogbo Main & $105(50.5)$ & $103(49.5)$ & 0.016 \\
\hline & $\begin{array}{l}\text { Campus } \\
\text { Management and Social } \\
\text { Sciences'/Okuku }\end{array}$ & $71(60.2)$ & $47(39.8)$ & \\
\hline & Humanities and Culture/ Ikire & $82(66.1)$ & $42(33.9)$ & \\
\hline \multirow[t]{3}{*}{ Education } & Secondary/ Post-Secondary & $229(70.7)$ & $95(29.3)$ & $<0.001 \ddagger$ \\
\hline & First or Masters degree & $25(29.8)$ & $59(70.2)$ & \\
\hline & PhD Equivalent or higher & $4(9.5)$ & $38(90.5)$ & \\
\hline \multirow{3}{*}{$\begin{array}{l}\text { Respondents' } \\
\text { status }\end{array}$} & Students & $219(72.8)$ & $82(27.2)$ & $<0.001$ \\
\hline & Academic Staff & $9(12.7)$ & $62(87.3)$ & \\
\hline & Non Academic Staff & $30(38.5)$ & $48(61.5)$ & \\
\hline
\end{tabular}

$\$$ Likelihood Ratio used

DOI: http://dx.doi.org/10.4314/ejhs.v27i6.12 


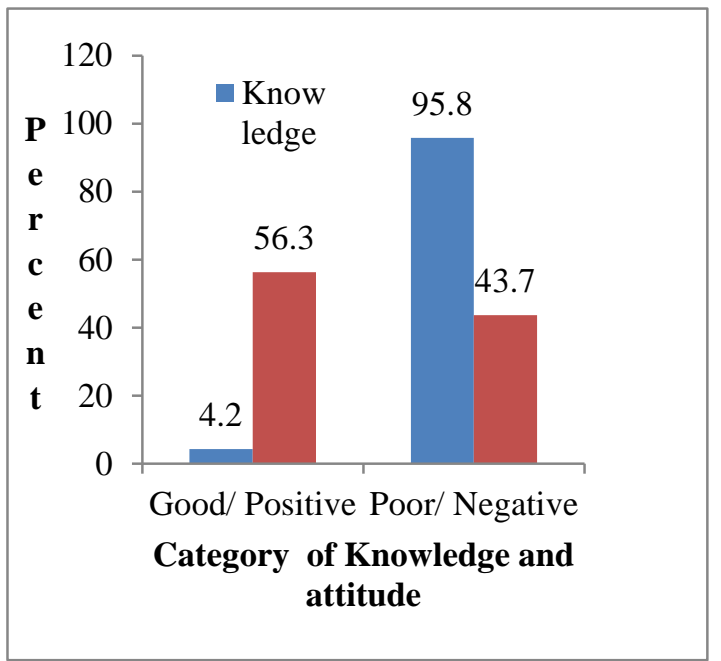

In Table 3, seven out of the eight people who had good knowledge of the SDGs were already enlightened on the SDGs through various programmes while all eight took personal efforts to learn about the SDGs. . None of the nonacademic staff had good knowledge of the SDGs while $2.4 \%$ of students and $9.7 \%$ of academic staff respectively had good knowledge.

With regard to attitude, $70.4 \%$ of respondents in the middle age group, $71.1 \%$ of those with at least a $\mathrm{PhD}$ or its equivalent and $79.0 \%$ of the academic staff had significantly positive attitudes compared to their counterparts. and those who already had an educative session or took time out to study about the SDGs.

Figure 1: Knowledge and attitude categories of respondents on SDGs [n=192]

Table 3: Respondents' knowledge and attitude on SDGs related with selected socio-demographic and other characteristics $(\mathrm{n}=192)$.

\begin{tabular}{|c|c|c|c|c|c|c|c|}
\hline \multirow[t]{3}{*}{ Variable } & \multirow[t]{3}{*}{ Sub-variables } & \multicolumn{6}{|c|}{ TEST OF } \\
\hline & & \multicolumn{2}{|c|}{ Knowledge $(n=192)$} & \multicolumn{3}{|c|}{ Attitude $(n=192)$} & \multirow{2}{*}{$\begin{array}{l}\text { p- } \\
\text { value }\end{array}$} \\
\hline & & $\begin{array}{l}\operatorname{Poor}(\%) \\
n=184\end{array}$ & $\begin{array}{l}\text { Good( } \\
\%) n=8\end{array}$ & $\begin{array}{l}\text { p } \\
\text { value) }\end{array}$ & $\begin{array}{l}\text { Negative(\%) } \\
\mathrm{n}=84\end{array}$ & $\begin{array}{l}\text { Positive(\%) } \\
\text { n=108 }\end{array}$ & \\
\hline \multirow[t]{3}{*}{ Age-group } & Youths & $89(97.8)$ & $2(2.2)$ & $\#(.329$ & $50(54.9)$ & $41(45.1)$ & 0.008 \\
\hline & Young Adults & $45(95.7)$ & $2(4.3)$ & & $18(38.3)$ & $29(61.7)$ & \\
\hline & Middle- aged & $50(92.6)$ & $4(7.4)$ & & $16(29.6)$ & $38(70.4)$ & \\
\hline \multirow[t]{2}{*}{ Sex } & Male & $96(94.1)$ & $6(5.9)$ & $\S 0.366$ & $38(37.3)$ & $64(62.7)$ & 0.053 \\
\hline & Female & $88(97.8)$ & $2(2.7)$ & & $46(51.1)$ & $44(48.9)$ & \\
\hline \multirow{3}{*}{$\begin{array}{l}\text { Colleges/ } \\
\text { Campuses }\end{array}$} & $\begin{array}{l}\text { CHS \& CSET/ } \\
\text { Osogbo }\end{array}$ & $98(95.1)$ & $5(4.9)$ & $\| 0.774$ & $42(40.8)$ & $61(59.2)$ & 0.495 \\
\hline & $\begin{array}{l}\text { Management and } \\
\text { Social Sciences'/ }\end{array}$ & $45(95.7)$ & $2(4.3)$ & & $24(51.1)$ & $23(48.9)$ & \\
\hline & $\begin{array}{l}\text { Okuku } \\
\text { Humanities and } \\
\text { Culture/ Ikire }\end{array}$ & 41(97.6) & $1(2.4)$ & & $18(42.9)$ & $24(57.1)$ & \\
\hline \multirow[t]{3}{*}{ Education } & Secondary/ Post Sec. & $93(97.9)$ & $2(2.1)$ & $\| 0.301$ & $54(56.8)$ & $41(43.2)$ & 0.001 \\
\hline & $\begin{array}{l}\text { First or Masters } \\
\text { degree }\end{array}$ & $56(94.9)$ & $3(5.1)$ & & $19(32.2)$ & $40(67.8)$ & \\
\hline & $\begin{array}{l}\text { PhD Equivalent or } \\
\text { higher }\end{array}$ & $35(92.1)$ & $3(7.9)$ & & $11(28.9)$ & $27(71.1)$ & \\
\hline \multirow{3}{*}{$\begin{array}{l}\text { Had any form of } \\
\text { education/ } \\
\text { enlightenment on } \\
\text { SDGs }\end{array}$} & Yes & $60(89.6)$ & $7(10.4)$ & $\| 0.006$ & $25(37.3)$ & $42(62.7)$ & $\| 0.198$ \\
\hline & No & 115(99.1) & $1(0.9)$ & & $53(45.7)$ & $63(54.3)$ & \\
\hline & Not sure & $9(100.0)$ & $0(0.0)$ & & $6(66.7)$ & $3(33.3)$ & \\
\hline \multirow{2}{*}{$\begin{array}{l}\text { Taken time out to } \\
\text { read/find out more } \\
\text { on the SDGs? }\end{array}$} & Yes & $69(89.6)$ & $8(10.4)$ & $\S 0.002$ & $33(42.9)$ & $44(57.1)$ & 0.956 \\
\hline & No & $115(100)$ & $(0.0)$ & & $51(44.3)$ & $64(55.7)$ & \\
\hline \multirow[t]{3}{*}{ Respondents' status } & Students & $80(97.6)$ & $2(2.4)$ & $\| 0.016$ & $49(59.8)$ & $33(40.2)$ & \\
\hline & Academic Staff & $56(90.3)$ & $6(9.7)$ & & $13(21.0)$ & $49(79.0)$ & $<0.001$ \\
\hline & Non Academic Staff & $48(100.0)$ & $0(0.0)$ & & $22(45.8)$ & $26(54.2)$ & \\
\hline
\end{tabular}

DOI: http://dx.doi.org/10.4314/ejhs.v27i6.12 


\section{DISCUSSION}

Over a year into the implementation of the SDGs, a little over two-fifths of the study respondents were aware of the SDGs. This can be considered to be low as the SDGs has as its motto "no one must be left behind". . In a global survey of the SDGs done in 2016, involving 13 countries including the African countries of Nigeria and Kenya, the level of awareness ranged from $16 \%$ in Russia to $44 \%$ in India, with the African countries having $34 \%$ and $30 \%$ respectively (9).The level of awareness in this study is higher than that of the global survey for Nigeria possibly because of the one-year gap in the conduct of both studies. It is expected that more people would become aware as time goes on, besides this study was done in a university community and not the general population. In another survey done across Europe in 2015, among 27,672 respondents (10), the level of awareness on SDGs was 36\%, which is lower than what was obtained in this study, although varied data collection times may account for the difference.

Further questions asked by the researchers in this study showed that those who claimed to be aware may not really be aware and many may be confusing the SDGs with the MDGs. For instance, a sixth of those who were aware said they heard of the SDGs in or before the year 2012. In reality, this is not likely to be true as the idea of SDGs as the new global developmental agenda to succeed the reigning MDGs was first mooted around 2012 at the Rio+20 conference(11), and did not really gain ground until the year 2015. One of the problems associated with the MDGs was the low level of awareness in both developed and developing countries (12-16). The level of awareness has been described as the backbone of achievement, (15), and it is generally believed that without adequate awareness there can be no attainment as the public will not be able to hold pertinent stakeholders accountable. The low level of awareness of the SDGs in the ivory tower portends a significant threat and danger to the attainment of the SDGs as very few groups or communities, if any, will have a higher level of awareness. Low level of awareness in the university community is inimical to SDGs attainment because it may imply not just a low level of teaching and learning about the SDGs but also little or no research on SDGs related issues. The importance of the educational system as the focal enlightenment point on SDGs has been duly recognized by international bodies. High-level officials of the UN and UNESCO met in late 2016 and deliberated on the prospects of mobilising the global education system to increase public awareness of the SDGs. The aim of such education is that all people, any and everywhere, will be aware of their rights and responsibilities as per the SDGs (17).

Concerning sources of awareness on the SDGs, it is not entirely surprising that radio/ TV took the lead, traditionally, radio and TV remain the leading sources of awareness in this part of the world. It is, however, noteworthy that the use of the internet and attendance of conferences were quite close to the usage of radio/TV. This may not be unconnected with the setting in which the study was carried out, as many of the respondents are likely to be avid internet users and/or lecture/ conference attendees. Globally, the social media is becoming a veritable source of information about many issues. However, only a fifth of the respondents acknowledged the social media as one of the sources of their awareness. The need to increasingly use the social media as a source of awareness/enlightenment about the SDGs has been duly recognized in Nigeria (18). Less than $5 \%$ of the respondents stated "on official duty" as one of the sources of awareness on SDGs, this is quite low and will not hasten the attainment of the SDGs. If truly no one is to be left behind in the attainment of the SDGs, then the earlier the SDGs are integrated into the learning and working culture or environment in any and every setting, the better it will be for SDGs implementation and ultimately its attainment. Although the level of awareness of the SDGs could be said to be fair or just low, the level of knowledge was terribly low with less than $5 \%$ of the respondents who were aware having good knowledge of the SDGs. The low level of knowledge might not be unconnected with the fact that intersectoral collaboration which has already been recognized by the OSSAP-SDGs (Office of the Senior Special Assistant to the President on SDGs) as a key principle for attaining the SDGs, (18) is inadequate and thus needs to be strengthened. There is an urgent need for all sectors, inclusive of the educational sector, to have a real buy-in into the SDGs and make it the fulcrum of their

DOI: http://dx.doi.org/10.4314/ejhs.v27i6.12 
developmental and/or strategic plans. If there will be any significant change in the understanding of the SDGs, positive attitudes will be required. Although over half of the respondents had positive attitude towards SDGs in this study. However, this is still grossly insufficient in the light of the SDGs' aim of leaving no one behind. A situation in which only $84.4 \%$ of the respondents were willing to learn more about the SDGs and only about $60 \%$ were ready to invest their time and efforts in learning more about the SDGs despite the fact that over $95 \%$ had poor knowledge is clearly undesirable.

This study attempted to look at individual factors associated with knowledge and attitude towards the SDGs. Having had any form of enlightenment on SDGs or having taken time out to read/find out more on the SDGs as well as being an academic staff were significantly associated with respondents having good knowledge of SDGs. This is to be expected as those who are enlightened either by personal efforts or other means stand a better chance of displaying good knowledge compared to those who are ignorant. There were differential levels of knowledge among study respondents with more academic staff having good knowledge. With regard to attitude, more academic staff also had good attitude. The 'dominance' of academic staff with regard to the knowledge of and attitudes towards the SDGs might not be unconnected with the academic nature of their work The things that shape people's attitudes are often multi-factorial, and the individual and societal factors involved in people's attitudes towards the SDGs may be the subject of further research.

The implications of the findings of this study are grave and far-reaching. The university system is the zenith of learning/education, and if the level of awareness and knowledge, as well as attitude towards the SDGs, is this low, then the societal level will be far lower and the SDGs paradigm that no one is left behind will remain a mirage. The sheer number of educational institutions in Nigeria with multitudes of students and staff should make the educational sector a priority setting for SDGs awareness and implementation. Strategies including policies and programmes must be put in place to integrate the SDGs into the university system. Educational systems have a lot to offer and are expected to define learning objectives and contents compliant with the SDGs, introduce pedagogies and curricula that empower learners to know about and implement SDGs, and themselves embrace sustainability principles in their management structures (19). The 2030 Agenda in itself gave a premium place to education as education is a standalone goal (SDG 4) and many education related targets and indicators are present in the remaining 16 goals. Education is thus a means for attaining all the other SDGs as the SDGs are inter-linked and the fulfillment of one goal is likely to enhance the fulfillment of other goals $(1,20)$. As the year 2030 looms on the horizon, it is imperative that curricula at the tertiary and other levels of education be spiced with the SDGs. The lead author of this paper recently introduced the SDGs into an environmental health course he coordinated for year three public health and nursing science students, in line with the environment being a major dimension of the SDGs, and virtually all of the students heard about the SDGs for the very first time. Many graduates of universities in Nigeria will leave school without having ever heard of the SDGs unless efforts are intensified to spread the ideals of the SDGs via SDGs integrated curricula. It is when the SDGs are brought to the forefront of activities in the university system that staff and students can have the right perspectives towards the SDGs. It is vital that each educational institution integrates the principles of sustainable development into their mission statements, with emphasis on today's development not adversely affecting future development.

In conclusion, this study is limited by lack of comparative hard data on the awareness of, knowledge about and attitude towards the SDGs in a university or similar setting, however the findings are revealing and will provide invaluable data on these and consequently stimulate efforts aimed at improving the level of awareness, knowledge and positive attitude towards the SDGs in educational settings. The SDGs are for all nations and peoples and for all segments of society (1), therefore pertinent individual and population-level methods of enlightening people about the SDGs becomes imperative and must be put in place in all settings, starting from the education sector.

\section{ACKNOWLEDGEMENT}

The authors acknowledge the efforts of Dr. Olorunfemi Ogundele and Dr, E.G Adepoju for the

DOI: http://dx.doi.org/10.4314/ejhs.v27i6.12 
roles they played in the validation of the questionnaire/principal component analyses.

\section{REFERENCES}

1. United Nations. Transforming Our World: The 2030 Agenda for Sustainable Development. 2015. Accessed March 25, 2017. Available at https://sustainabledevelopment.un.org/content/doc uments/21252030\%20Agenda\%20for\%20Sustaina ble\%20Development\%20web.pdf

2. United Nations. The Millennium Development Goals Report. 2015

3. Inter-Agency and Expert Group on SDG Indicators (IAEG-SDGs). Final list of proposed Sustainable Development Goal indicators. March 2016 Accessed on 12/12/2016. Available at http://unstats.un.org/sdgs/indicators/Official\%20Li st $\% 20$ of\%20Proposed\%20SDG\%20Indicators.pdf

4. UNDP Nigeria. 2030 Agenda for Sustainable Development. Accessed on 12/12/2016. Available at:

http://www.ng.undp.org/content/nigeria/en/home/p ost-2015/sdg-overview.html

5. UNESCO. Education for Sustainable Development. Accessed 20th March, 2017. Available at http://en.unesco.org/themes/education-sustainabledevelopment

6. Office of the Senior Special Assistant to the President on MDGs. Millennium Development Goals End-point Report 2015 Nigeria.

7. United Nations Economic Commission for Africa, African Union, African Development Bank and United Nations Development Programme. MDG Report 2015: Assessing Progress in Africa toward the Millennium Development Goals. 2015

8. United Nations. The Millennium Development Goals Report 2014.

9. GlobeScan. Awareness of SDGs versus MDGs: How Engaged Are Global Citizens? OECD DevCom Annual Meeting. 2016. Accessed on 16 June 2017. Available at https://www.oecd.org/dev/pgd/Session4_Bouhana_ GlobeScan_OECDTalk_MDGsvsSDGs_2016.pdf

10. European Union. Special Eurobarometer 441 Report. EU Development Cooperation and Aid. The European Year for Development- Citizens' views on Development, Cooperation and Aid. 2016. Accessed on 16 June 2017. Available at http://ec.europa.eu/europeaid/special- eurobarometer-441-european-year-developmentcitizens-viewson-development-cooperation-andaid_en

11. United Nations. Sustainable Development Knowledge Platform. Future We Want - Outcome document. Accessed on 25March 2017. Available at

https://sustainabledevelopment.un.org/futurewewa nt.html

12. Connolly E, Doyle J, Dwyer F. "Public opinion and development issues: A survey of the Irish university student opinions". Irish Studies in International Affairs. 2008;19:209-226.

13. Mc Donnell I. An International Perspective on Communication Strategies for the Millennium Development Goals, NCDO and OECD Development Centre.

14. Fransman J, MacDonald AL, Mc Donnell I, PonsVignon N. OECD Development Centre. Working Paper No. 238. Public opinion polling and the millennium development goals. October 2004.

15. Nashash H. Level of millennium development goals awareness among students at Princess Alia University College. European Scientific Journal2013; 9 (16):43-54.

16. Ogbodo JN. Nigerian public awareness and knowledge of the Millennium Development Goals (MDGs) and their Level of implementation in Nigeria. European Scientific Journal 2015;11(23):301-16.

17. UNESCO. At UNESCO, President of the UN General Assembly calls for a "push in SDG awareness." UNESCOPRESS 18.11.2016. Accessed on March $1^{\text {st }}$, 2017. Available at: http://www.unesco.org/new/en/naturalsciences/ioc-oceans/single-viewoceans/news/at_unesco_president_of_the_un_gene ral_assembly_calls_for_a/

18. Office of the Senior Special Assistant to the President on MDGs. Nigeria's Road to SDGs | Country Transition Strategy October 2015

19. UNESCO Education for Sustainable Development Goals; Learning Objectives. 2017 Accessed March 25, 2017. Available at http://unesdoc.unesco.org/images/0024/002474/24 7444e.pdf

20. United Nations Environment Programme. The United Nations Environment Programme and the 2030 Agenda; Global Action for People and the Planet. 2015. 